\title{
Loss of regular oscillatory insulin secretion in islet cell antibody positive non-diabetic subjects
}

\author{
P.J.Bingley ${ }^{1}$, D.R.Matthews ${ }^{2}$, A.J.K. Williams ${ }^{1}$, G.F. Bottazzo ${ }^{3}$ and E. A.M. Gale ${ }^{1}$ \\ ${ }^{1}$ Department of Diabetes and Metabolism, St. Bartholomew's Hospital, London, ${ }^{2}$ Diabetes Research Laboratories, Nuffield Department \\ of Clinical Medicine, Radcliffe Infirmary, Oxford, ${ }^{3}$ Department of Immunology, Royal London Hospital, London, UK
}

Summary. Basal insulin secretion was compared in nine islet-cell antibody positive, non-diabetic first-degree relatives of children with Type 1 (insulin-dependent) diabetes mellitus and nine normal control subjects matched for age, sex and weight. Acute insulin responses to a $25 \mathrm{~g}$ intravenous glucose tolerance test were similar in the two groups (243 (198-229) vs $329(285-380) \mathrm{mU} \cdot \mathrm{l}^{-1} \cdot 10 \mathrm{~min}^{-1}$, mean $( \pm \mathrm{SE}), p=0.25)$. Fasting plasma insulin was assayed in venous samples taken at one min intervals for $2 \mathrm{~h}$. Time series analysis was used to demonstrate oscillatory patterns in plasma insulin. Autocorrelation showed that regular oscillatory activity was generally absent in the islet-cell antibody- positive group, whereas a regular 13 min cycle was shown in control subjects $(p<0.0001)$. Fourier transformation did, however, show a 13 min spectral peak in the islet-cell antibody positive group, consistent with intermittent pulsatility. We conclude that overall oscillatory patters of basal insulin secretion are altered in islet-cell antibody positive subjects even when the acute insulin response is within the normal range.

Key words: Type 1 (insulin-dependent) diabetes mellitus, islet-cell antibodies, insulin secretion.
Prospective study of individuals developing Type 1 (insulin-dependent) diabetes mellitus has identified a long prodrome characterized by the appearance of islet-cell antibodies (ICA) and other immunological abnormalities $[1,2]$. Islet-cell antibodies provide the best available marker of future Type 1 diabetes. A first-degree relative of a child with Type 1 diabetes with an ICA titre greater than 4 JDF units has a $40 \%$ risk of developing the disease within 9 years compared with less than $0.5 \%$ in one who is ICA negative [3].

Recognised metabolic changes include diminished insulin responses to intravenous glucose, impaired glucose tolerance and subclinical hyperglycaemia, all of which may precede the onset of clinical symptoms by months or years [4-6]. Even so, they reflect a relatively late stage in the disease process, and there is a need for earlier and more sensitive markers to identify pre-diabetic individuals at a time when more functioning Beta cells might potentially be preserved.

In healthy individuals blood glucose is tightly regulated, a process that requires precise control of insulin secretion. Basal insulin levels show regular oscillation with a period of about $13 \mathrm{~min}$ with synchronous oscillation of $\mathrm{C}$ - peptide indicating pulsatile insulin secretion $[7,8]$. These short-term oscillations occur within the longer cycles (approximately $40 \mathrm{~min}$ ) of a feedback loop and may improve homeostasis by increasing sensitivity to changes in glucose. Glucose levels are more stable in normal subjects with regular insulin oscillations than in those in whom oscillatory patterns have been altered by truncal vagotomy or removal of the head of the pancreas [9]. Alterations in pulsatile insulin secretion have been reported consistently in states of abnormal glucose tolerance in man and other animals $[10,11]$. These include patients with Type 2 (noninsulin-dependent) diabetes and their first degree relatives with even minimal impairment of glucose tolerance [12]. In these subjects the normal relationship between basal glucose and insulin peaks is disturbed and glucose levels vary more widely $[7,9]$. Data from several research groups also show that pulsatile delivery of insulin improves the efficiency of its action $[13,14]$.

We hypothesized that oscillatory insulin secretion might be affected at an early stage of the Type 1 diabetes prodrome, and therefore investigated a population of ICA-positive individuals to establish the presence and prognostic significance of such an abnormality. 
Table 1. Clinical characteristics, fasting glucose and insulin and acute insulin response in nine islet-cell antibody positive first-degree relatives of children with Type 1 (insulin-dependent) diabetes mellitus and nine control subjects

\begin{tabular}{|c|c|c|c|c|c|c|c|c|c|c|c|}
\hline & Age & Sex & $\begin{array}{l}\text { Body mass } \\
\text { index } \\
\left(\mathrm{kg} / \mathrm{m}^{2}\right)\end{array}$ & $\begin{array}{l}\text { Peak } \\
\text { ICA } \\
\text { (JDF units) }\end{array}$ & $\begin{array}{l}\text { Fasting } \\
\text { blood } \\
\text { glucose } \\
(\mathrm{mmol} / \mathrm{l})\end{array}$ & $\begin{array}{l}\text { Fasting } \\
\text { plasma } \\
\text { insulin } \\
(\mathrm{mU} / \mathrm{l})\end{array}$ & $\begin{array}{l}\text { 1st phase } \\
\text { insulin } \\
\text { (incremental } \\
0-10 \text { min area: } \\
\mathrm{mU} \cdot 1^{-1} \text {. } \\
10 \mathrm{~min}^{-1} \text { ) }\end{array}$ & $\begin{array}{l}\text { 2nd phase } \\
\text { insulin } \\
\text { (incremental } \\
10-60 \mathrm{~min} \\
\text { area: } \\
\mathrm{mU} \cdot \mathrm{l}^{-1} \\
50 \mathrm{~min}^{-1} \text { ) }\end{array}$ & $\begin{array}{l}\text { Glucose } \\
\text { disposal } \\
\text { rate } \\
(\% / \mathrm{min})\end{array}$ & $\begin{array}{l}\text { HOMA } \\
\text { estimate } \\
\text { Beta-cell } \\
\text { function } \\
(\%)\end{array}$ & $\begin{array}{l}\text { HOMA } \\
\text { estimate } \\
\text { insulin } \\
\text { resis- } \\
\text { tance } \\
(\%)\end{array}$ \\
\hline \multicolumn{12}{|c|}{ ICA positive } \\
\hline \multicolumn{12}{|c|}{ Control subjects } \\
\hline $\begin{array}{l}1 . \\
2 . \\
3 . \\
4 . \\
5 . \\
6 . \\
7 . \\
8 . \\
9 .\end{array}$ & $\begin{array}{l}43 \\
23 \\
33 \\
21 \\
24 \\
37 \\
21 \\
24 \\
20\end{array}$ & $\begin{array}{l}M \\
F \\
M \\
F \\
M \\
F \\
F \\
M \\
M\end{array}$ & $\begin{array}{l}25 \\
19 \\
20 \\
22 \\
24 \\
22 \\
21 \\
27 \\
26\end{array}$ & $\begin{array}{l}- \\
- \\
- \\
- \\
- \\
- \\
- \\
- \\
-\end{array}$ & $\begin{array}{l}4.6 \\
3.9 \\
3.6 \\
4.0 \\
3.8 \\
4.5 \\
4.0 \\
3.9 \\
3.8\end{array}$ & $\begin{array}{l}9.9 \\
8.6 \\
4.5 \\
6.5 \\
5.4 \\
5.6 \\
6.1 \\
6 \\
4.6\end{array}$ & $\begin{array}{l}185 \\
374 \\
349 \\
481 \\
351 \\
317 \\
155 \\
623 \\
364\end{array}$ & $\begin{array}{r}750 \\
1817 \\
885 \\
- \\
633 \\
680 \\
620 \\
625 \\
504\end{array}$ & $\begin{array}{l}1.02 \\
1.09 \\
1.6 \\
- \\
2.06 \\
0.98 \\
1.58 \\
2.43 \\
1.5\end{array}$ & $\begin{array}{r}133 \\
168 \\
132 \\
133 \\
132 \\
95 \\
128 \\
134 \\
119\end{array}$ & $\begin{array}{l}39 \\
47 \\
93 \\
62 \\
76 \\
69 \\
66 \\
68 \\
89\end{array}$ \\
\hline & \multicolumn{2}{|c|}{$27.3 \pm 8.3$} & $22.9 \pm 2.8$ & & $4.0 \pm 0.3$ & $6.4 \pm 1.8$ & $\begin{array}{l}329 \\
(285-380)\end{array}$ & $\begin{array}{l}752 \\
(640-883)\end{array}$ & $1.53 \pm 0.18$ & $130 \pm 6$ & $67 \pm 6$ \\
\hline
\end{tabular}

${ }^{a}$ Mean $\pm \mathrm{SD}$, remainder expressed as mean \pm standard error

ICA, islet cell antibodies; HOMA, homeostasis model assessment

\section{Subjects and methods}

\section{Subjects}

Nine individuals with peak ICA greater than 4 JDF units, one parent and eight siblings of children with Type 1 diabetes, and nine ICAnegative control subjects with no family history of diabetes were studied. Control subjects were matched for age, sex and weight (Table 1). All individuals in both groups had normal fasting blood glucose levels (Table 1). Five of the ICA positive group had oral glucose tolerance tests in the year preceding the study; four were nor$\mathrm{mal}$ and one showed impaired glucose tolerance (WHO criteria), with a 2-h whole blood glucose of $6.7 \mathrm{mmol} / 1$ (subject 7).

All the ICA-positive individuals were participants in the Bart'sWindsor or Bart's-Oxford family studies. Ascertainment methods and inclusion criteria have been described elsewhere $[15,16]$. At the time the present study was undertaken, a total of 16 subjects under follow-upin the family studies fulfilled the entry criteria of age greater than 16 years, with ICA greater than 4 JDF units on at least three occasions during the previous 5 years. The median duration of known ICA positivity was 7.8 years (range 2.1-11). Two ICA positive individuals and their control subjects were taking low-dose combined oral contraceptives; none were using other medication. Informed consent was obtained from all subjects and the study was approved by the City and Hackney District Health Authority Ethics Committee.

\section{Methods}

All studies were performed at 09.00 hours. Subjects attended the hospital after an overnight fast, having previously been on a normal diet with no carbohydrate restriction. A 16 gauge double-lumen catheter was introduced into a forearm vein under local anaesthesia for continuous blood sampling. Heparin was delivered to the tip via the outer lumen giving a final sample concentration of $80 \mathrm{U} / \mathrm{ml}$. The hand was warmed to arterialize the sampled blood. Venous samples were taken continuously, as $1 \mathrm{~min}$ aliquots, for 110-120 min by peristaltic pump at a rate of $1.3 \mathrm{ml} / \mathrm{min}$, following a 30 min rest after cannulation. Samples were centrifuged at $4^{\circ} \mathrm{C}$ within $10 \mathrm{~min}$ and stored at $-20^{\circ} \mathrm{C}$ immediately after separation.

After the period of continuous sampling, $25 \mathrm{~g}$ dextrose as a $50 \%$ solution was given into a second cannula at a rate of $20 \mathrm{~g} / \mathrm{min}$ using a syringe pump (Sage syringe pump, model 351, Arnold R. Horwell Ltd, London, UK). Samples were taken at baseline and 1, 3, 5, 7, 10, $15,20,30,45$ and $60 \mathrm{~min}$ after the midpoint of the glucose infusion.

\section{Assays}

Insulin. All samples from each study were assayed in duplicate in the same assay. Immunoreactive insulin was determined using a doubleantibody radioimmunoassay with guinea-pig anti-human-insulin first antibody (in house) and sheep anti-guinea pig Fc (Internation of Laboratory Services, London, UK) as the second antibody. ${ }^{125} \mathrm{I}$ labelled human insulin (specific activity $1500 \mathrm{Ci} / \mathrm{mmol}$; Medgenix, Fleurus, Belgium) was used as tracer with human insulin standards (Novo Biolabs, Bagsvaerd, Denmark). The median intra-assay coefficient of variation of the duplicates for the 18 assays at mean insulin concentration $5.7 \mathrm{mU} / \mathrm{l}$ was $5.8 \%$ (range $3.6-18.8 \%$ ).

Glucose. Samples for glucose analysis were taken into fluoride oxalate and whole blood was assayed within $2 \mathrm{~h}$ by a glucose oxidase 

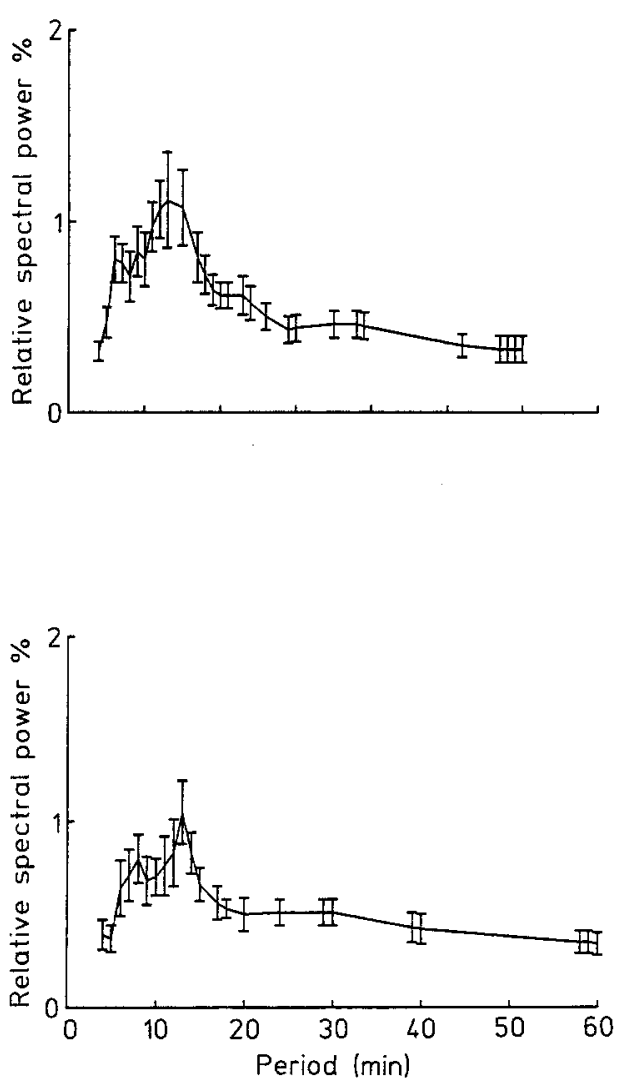

Fig.1. Pooled power spectra of Fourier transforms of basal insulin secretion in control (upper panel) and islet-cell antibody positive subjects (lower panel). Spectral power in absolute units. Bars \pm SEM

method using a YSI model $23 \mathrm{AM}$ glucose analyser (Yellow Springs Instrument Co., City, Ohio, USA). The interassay coefficient of variation was $5.5 \%$ at $2.2 \mathrm{mmol} / \mathrm{l}$ and $2.7 \%$ at $11.6 \mathrm{mmol} / \mathrm{l}$.

Islet cell antibodies. ICA were determined by an indirect immunofluorescent technique with conversion to JDF units as described elsewhere $[17,18]$.

\section{Statistical methods}

Time series analysis. Three min moving averages: individual data sets were averaged using a 3 -point moving average on the duplicates ( $n=6$ for each point estimate) which reduces the size of fluctuations of short duration due to assay and experimental noise and increases the precision of the estimate by $\sqrt{6}$.

Stationarisation. Data were stationarised by spline detrending for autocorrelation and by differencing about the mean (which is equivalent to examining the first derivative of the data) for Fourier transform analysis. These methods eliminate long-term trends before undertaking time series analysis (TSA).

Two types of TSA were used: (i) Fourier transformation. Fourier transforms dissect oscillatory data into all their attributes of frequency [19]. Any complex signal can thus be described in terms of its dominant and sub-dominant harmonics. Fourier transforms have the advantage of providing a complete description of oscillations and can be represented graphically as a power spectrum (i.e. power at all the relevant frequencies or periods). The major peak in spectral power corresponds to the dominant frequency of oscillation. This method of analysis, in contrast to autocorrelation, will detect irregu- lar as well as regular pulsation. Fourier transformed analyses were pooled for ICA positive relatives and control subjects and a value for the mean and standard error of the oscillatory power was obtained at each frequency. These values can be regarded as normally distributed and their variance can be used to assess the SEM. Significance between peaks can thus be represented by error bars or formally assessed by Student's $t$-test.

(ii) Autocorrelation. Autocorrelation was used to identify significant regular oscillation in plasma insulin levels. Correlation coefficients were calculated between the original plot of plasma insulin against time and sequential 'copies' of the data generated by moving the original data by increments of $1 \mathrm{~min}$. The initial correlation is, by definition, +1 and the correlation coefficient $(r)$ then falls to reach a nadir when the data are 180 degrees out of phase. The correlation coefficients were plotted against time delay (lag time) to produce correlograms [18]. The period of oscillation is defined as the lag time to the first significant maxima of the $r$-value following an initial trough. Autocorrelograms were pooled by Z-transformation of the $r$-values (which renders them normally distributed). The significance was assessed from Fisher's values [19, 20].

Amplitude of oscillation. The mean total amplitude of oscillation for each data array was calculated as the root-mean square of the detrended data set $\times 2 \sqrt{2}[9]$.

\section{Statistical analysis}

Standard deviation has been used as a measure of dispersion in anthropometric data; otherwise standard errors are quoted. Comparisons between groups were made using parametric methods (unpaired $t$-test).
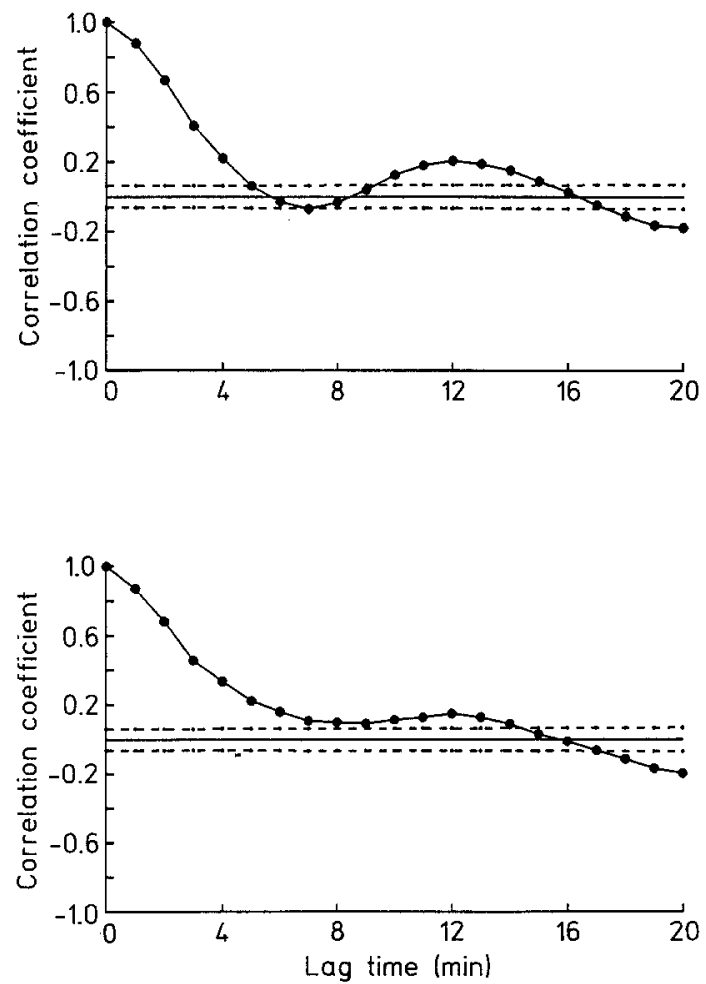

Fig. 2. Pooled autocorrelograms of basal insulin secretion from control (upper panel) and islet cell antibody positive subjects (lower panel). Dotted line at $p=0.05$. Regular oscillation is demonstrated in control subjects by the trough below the significance limit followed by a positive peak above the significance limit $(p<0.0001$ after Fisher's Z-transformation) in correlation coefficient 

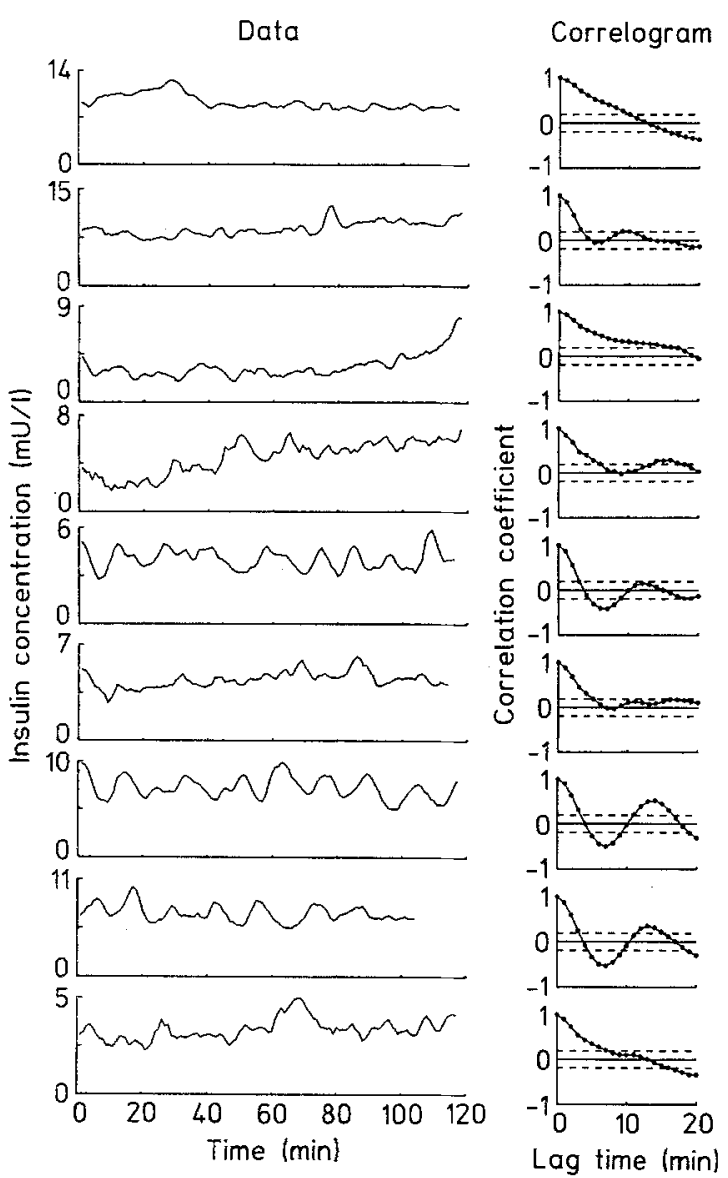

Fig.3. Three-min moving average of plasma insulin (left panels) and individual autocorrelograms (right panels) from control subjects 1-9 (from top down)

The acute (first phase) and late (second phase) insulin responses to the intravenous glucose tolerance test were calculated as the incremental $0-10 \mathrm{~min}$ and $10-60 \mathrm{~min}$ areas under the curve using trapezoidal integration. The responses were non-normal in distribution and standard errors were therefore derived after log transformation. The glucose disposal rate $(\mathrm{Kg})$ was expressed as the slope of the semi-logarithmic decline of blood glucose over the 10 to $30 \mathrm{~min}$ following glucose infusion [21]. Homeostasis model assessment (HOMA) was used to estimate insulin resistance and Beta-cell function from fasting plasma glucose and insulin concentrations [22].

\section{Results}

\section{Fasting glucose and insulin levels}

Fasting blood glucose was similar in ICA positive and control subjects $(4.0 \pm 0.14$ vs $4.0 \pm 0.11 \mathrm{mmol} / 1, p=0.8)$, as was fasting plasma insulin ( $5.4 \pm 0.52$ vs $6.4 \pm 0.6 \mathrm{mU} / \mathrm{l}$, $p=0.25$ ).

\section{Acute insulin responses}

First phase incremental insulin areas after glucose did not differ between ICA positive and control groups (243 (198-299) vs 329 (285-380)) $\mathrm{mU} \cdot 1^{-1} \cdot 10 \mathrm{~min}^{-1}$ respectively, $p=0.25$ ). All were above the first centile compared with a group of 50 non-diabetic ICA-negative control subjects previously studied in our laboratory.
Late insulin response, glucose disposal and estimated Beta-cell function and insulin resistance

There were no differences in mean late insulin responses (524 (428-641) vs $752(640-883) \mathrm{mU} \cdot \mathrm{l}^{-1} \cdot 50 \mathrm{~min}^{-1}$, $p=0.19)$, glucose disposal rates $(1.53 \pm 0.14$ vs $1.53 \pm$ $0.18 \% / \mathrm{min}, p=0.95$ ) or homeostasis model assessment derived estimates of Beta-cell function ( $121 \pm 8$ vs $130 \pm$ $6 \%, p=0.4$ ) or insulin resistance ( $81 \pm 9$ vs $67 \pm 6 \%$, $p=0.22$ ) between the ICA positive and control groups.

\section{Total oscillatory activity}

Figure 1 shows the pooled Fourier transformation analyses for ICA positive and control subjects. In both groups the dominant spectral power was seen at periods between 12 and 15 min with no difference between the peak spectral power in the two groups (mean absolute spectral power $6.0 \pm 1.0$ vs $8.5 \pm 1.7$ for ICA positive and control groups, respectively).

\section{Regular oscillatory activity}

Control subjects. Pooling of autocorrelation data showed a significant peak of regular oscillation at $13 \mathrm{~min}$ $(p<0.0001)$. The correlation coefficient fell from +1 to a nadir below zero after a lag-time of $6 \mathrm{~min}$, rising again to a
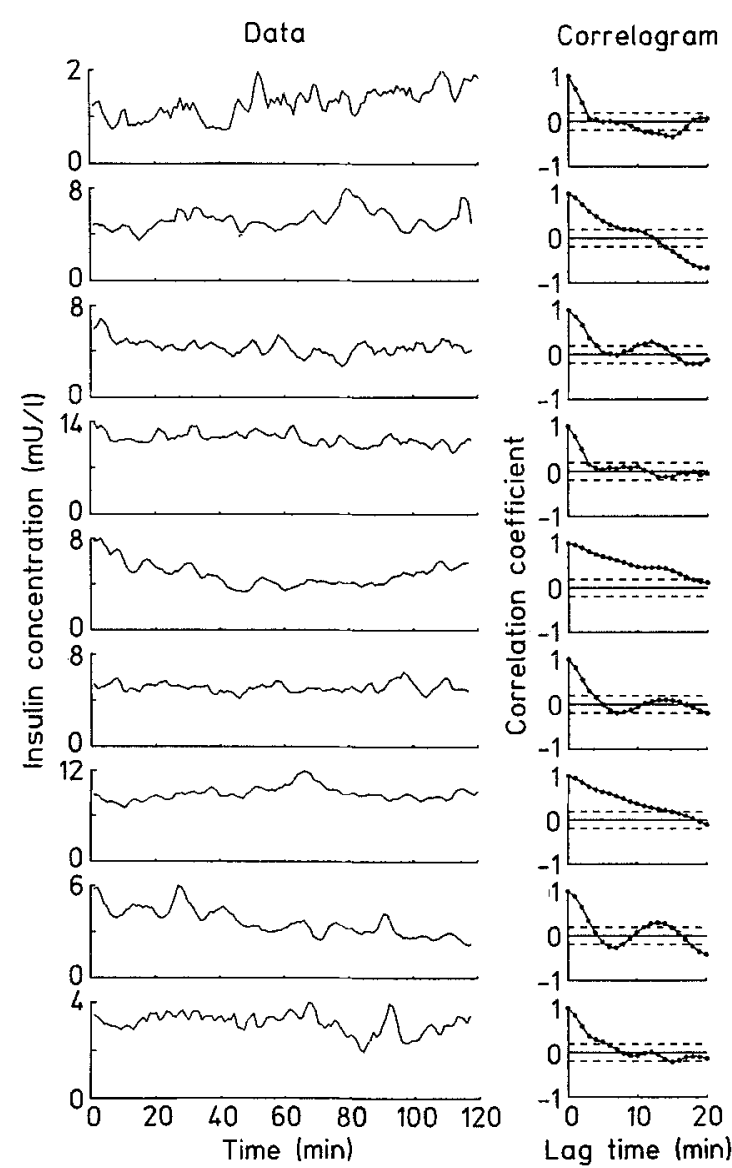

Fig. 4. Three-min moving average of plasma insulin (left panels) and individual autocorrelograms (right panels) from islet cell antibody positive subjects 1-9 (from top down) 
peak above the level of significance after 13 min (Fig.2). Significant positive peaks of autocorrelation at 12 to 14 min following an earlier nadir were detected in six of nine control subjects on individual correlograms (subjects 2, 4, 5, 6, 7 and 8) (Fig. 3).

ICA positive subjects. There was no evidence of regular oscillation when autocorrelation data from ICA positive subjects were pooled. The correlation coefficient fell gradually, with no clear nadir below the level of significance or significant positive peak. (Fig.2). Seven of nine ICA positive subjects showed no significant regular oscillatory activity on individual correlograms (subjects 1,2,4, 5, 6,7 and 9) (Fig.4).

\section{Amplitude of oscillation}

The mean amplitude of oscillation was similar in ICApositive and control subjects $(1.4 \pm 0.2$ vs $1.1 \pm 0.2 \mathrm{mU} / \mathrm{l}$, $p=0.4$ ).

\section{Discussion}

We have confirmed that regular oscillations of basal plasma insulin with a period of about $13 \mathrm{~min}$ can be demonstrated in healthy subjects [7,23], and have shown that this pattern is generally altered in ICA positive individuals. These retained dominant oscillatory activity with a period of $12-13 \mathrm{~min}$, as shown by Fourier transformation, but autocorrelation showed loss of regular pulsation, indicating that in this group secretion is either completely irregular or composed of short, intermittent periods of regular pulsation. We found no differences in the amplitude of oscillation in the two groups. This is in contrast with the observation that the amplitude of oscillation is reduced in the streptozotocin-treated baboon, although this did not occur until the fasting glucose had begun to rise [11], whereas in our study all subjects had a fasting glucose below $4.6 \mathrm{mmol} / 1$.

The oscillatory patterns that we describe are derived from analysis of pooled data from carefully chosen groups, which amplifies relatively subtle abnormalities, and it is important to stress that these findings are from pooled data, and have no time-series characteristics which are consistently discernible in individuals. The data do show that as a group the ICA positive individuals have abnormal insulin secretion qualitatively different from control subjects. Since the ICA positive individuals are all under long-term prospective review, this should in time allow the prognostic utility of these patterns of secretion to be assessed. Abnormalities of basal insulin secretion might also be present in ICA negative relatives, and further studies would be needed to exclude this possibility.

The earliest metabolic abnormality preceding the onset of Type 1 diabetes described hitherto has been impairment of the first-phase insulin response to intravenous glucose [4]. This abnormality is however of confirmed predictive value only when the response has fallen below the first centile, corresponding to an advanced stage of Beta-cell destruction. Its predictive value is also limited by the marked variability of response within the normal range [24] and the effect of physiological changes such as puberty [25]. Attenuation of the first-phase insulin response before the onset of Type 1 diabetes cannot simply be due to Beta-cell loss, since insulin responses to secretagogues other than glucose persist, implying an additional 'functional' Beta-cell deficit in glucose-stimulated insulin release [26]. Furthermore, C-peptide secretion rises during the remission or 'honeymoon' period following diagnosis, and there is currently no evidence that this is due to Beta-cell regeneration [27]. These observations suggest that derangement of the mechanisms that control secretion, whether altered Beta-cell recognition of the glucose stimulus, or an abnormal response to it, may be an important component of the early metabolic disorder.

Pulsatile secretion of insulin may be regulated by an intrinsic pancreatic pacemaker modulated by extra-pancreatic factors $[9,28]$. This is influenced by levels of both insulin and glucose and can be altered by infusion of either substance [9]. These factors cannot have been of importance in our study since basal levels of insulin and glucose were similar in both groups. Periodic insulin secretion requires coordination of the output from individual islets by a neural or paracrine network [29]. In Type 1 diabetes the pattern of autoimmune attack appears to be random, and at the time of diagnosis normal islets are interspersed with islets in which Beta cells are scanty or absent [30]. It is as yet unclear whether loss of regular oscillation reflects actual disruption of neural or paracrine pathways within the pancreas, developing in parallel with Beta-cell destruction, or whether the effect is due simply to cumulative Beta-cell loss.

Loss of regular pulsation of basal insulin secretion could have important direct effects upon glucose homeostasis. In the first place, secretion of insulin may itself be modulated by fluctuation in pancreatic arterial insulin levels. In the anaesthetised rat, continuous intraportal infusion of insulin attenuates glucose-stimulated insulin release whereas pulsatile infusion enhances it [31]. Loss of pulsatility might therefore be a factor in the loss of the first phase insulin response to intravenous glucose in ICA positive individuals through there is, as yet, no evidence that there is a causative link. Second, insulin action on the liver is enhanced by variation in portal insulin levels, and pulsatile delivery of exogenous insulin has a greater hypoglycaemic effect in man than continuous infusion. Pulsed delivery allows equivalent stimulation of peripheral glucose utilization and suppression of hepatic glucose output to be achieved with lower doses of insulin, in both Type 1 diabetic patients and normal subjects $[9,32,33]$. In other words, loss of pulsatility results in insulin resistance, and this has been a consistent finding in other situations in which loss of regular insulin pulsatility has been reported, for example obesity and old age [7, 23, 34].

The practical value of loss of regular oscillation in basal insulin levels as a marker of future diabetes is limited, in part because relatively little is known of the variability of this phenomenon in the normal population. It is clear that some normal subjects do not have regular 
oscillation, demonstrable by autocorrelation, and that some of the ICA positive group do. Some $10-50 \%$ of normal subjects have shown no significant peaks on autocorrelation in previous studies $[7,9,12]$, and this was the case with three of the nine normal control subjects in the present study. There is this no absolute diagnostic significance to individual observations. Sequential testing in normal or high risk individuals could improve the specificity of changes in oscillatory patterns. That two of the ICA positive subjects should have regular oscillations may be a significant finding in itself - we do not yet know whether those studied will develop diabetes and longitudinal studies would clearly be important to examine this hypothesis. It may be that retained regular oscillatory activity in an ICA positive individual is a sign of normal Beta-cell function, indicating that early progression to diabetes is unlikely. This is the case with relatives of patients with Type 2 diabetes [12], in whom regular oscillation has not been found in any individual who has subsequently developed diabetes.

We have shown that pulsatile insulin secretion may be deranged in ICA positive individuals with normal insulin responses to intravenous glucose and normal Beta-cell function and insulin sensitivity using simple modelling techniques, and could represent one of the earliest metabolic abnormalities preceding the onset of Type 1 diabetes. The altered pattern of basal insulin secretion may in turn have direct functional consequences in terms of Beta-cell secretion and hepatic glucose sensitivity. Loss of first phase insulin secretion represents a late metabolic abnormality associated with extensive Beta-cell loss. Better understanding of early metabolic abnormalities such as loss of regular oscillation of basal insulin secretion may in time allow accurate prediction and intervention earlier in the prodrome of Type 1 diabetes, at a time when more Beta cells are viable.

Acknowledgements. We thank Ms. H. Archibald for nursing help and Ms. M. Shattock for measuring islet cell antibodies. PJB is funded by the Medical Research Council. DRM is Joan and Richard Doll Senior Research Fellow at Green College, Oxford. The study is also supported by the British Diabetic Association, the Juvenile Diabetes Foundation and the Joint Research Board of St Bartholomew's Hospital.

\section{References}

1. Bosi E, Todd I, Pujol-Borrell R, Bottazzo GF (1990) Mechanisms of autoimmunity: relevance to the pathogenesis of Type 1 diabetes. Diab Metab Rev 3: 893-928

2. Colman PG, Eisenbarth GS (1988) Immunology of Type 1 diabetes - 1987 In: Alberti KGGM, Krall LP (eds) Diabetes annual/4. Elsevier, Amsterdam, pp 17-45

3. Bonifacio E, Bingley PJ, Dean BM et al. (1990) Quantification of islet-cell antibodies and prediction of insulin-dependent diabetes. Lancet 335: 147-149

4. Srikanta S, Ganda OP, Eisenbarth GS, Soeldner JS (1983) Isletcell antibodies and beta cell function in monozygotic triplets and twins initially discordant for Type 1 diabetes mellitus. N Engl J Med 308: 322-325

5. Rosenbloom AL, Hunt SS, Rosenbloom EK, Maclaren NK (1982) Ten-year prognosis of impaired glucose tolerance in sib- lings of patients with insulin-dependent diabetes. Diabetes 31 : 385-387

6. Tarn AC, Smith CP, Spencer KM, Bottazzo GF, Gale EAM (1987) Type 1 (insulin-dependent) diabetes: a disease of slow clinical onset? Br Med J 294: 342-345

7. Lang DA, Matthews DR, Peto J, Turner RC (1990) Cyclic oscillations of basal plasma glucose and insulin concentrations in human beings. N Engl J Med 301: 1023-1027

8. Goodner CJ, Walike BC, Koerker DJ et al. (1977) Insulin, glucagon and glucose exhibit synchronous, sustained oscillations in fasting monkeys. Science 195: 177-195

9. Matthews DR, Lang DA, Burnett M, Turner RC (1983) Control of pulsatile insulin secretion in man. Diabetologia 24:231-237

10. Matthews DR, Lang DA, Burnett M, Turner RC (1981) Brief irregular oscillations of basal plasma insulin and glucose concentrations in diabetic man. Diabetes 30: 435-439

11. Goodner CJ, Koerker DJ, Weigle DS, McCulloch DK (1989) Decreased insulin-and glucagon-pulse amplitude accompanying $\beta$ cell deficiency induced by streptozocin in baboons. Diabetes 38 : 925931

12. O'Rahilly S, Turner RC, Matthews DR (1988) Impaired pulsatile secretion of insulin in relatives of patients in non-insulin-dependent diabetes. N Engl J Med 318: 1225-1230

13. Matthews DR, Naylor RG, Jones RG, Ward GM, Turner RC (1983) Pulsatile insulin has greater hypoglycaemic effect than continuous delivery. Diabetes 32:617-621

14. Paolisso G, Sgambata S, Passariello N, Scheen A, D'Onofrio F, Lefebvre PJ (1987) Greater efficacy of pulsatile insulin in Type 1 diabetics critically depends on plasma glucagon levels. Diabetes 36: $566-570$

15. Gorsuch AN, Spencer KM, Lister J et al. (1981) Evidence for a long prediabetic period in Type 1 (insulin-dependent) diabetes mellitus. Lancet II: 145-147

16. Bingley PJ, Gale EAM (1989) The incidence of insulin-dependent diabetes in England: a study in the Oxford region $1985-6 . \mathrm{Br}$ Med J 298: 558-560

17. Bottazzo GF, Dean BM, Gorsuch AN, Cudworth AG (1980) Complement fixing islet cell antibodies in Type 1 diabetes. Possible monitors of active B-cell damage. Lancet I: 668-672.

18. Bonifacio E, Lernmark $\AA$, Dawkins RL (1988) Serum exchange and use of dilutions have improved precision of measurement of islet cell antibodies. J Immunol Meth 106: 83-88

19. Pearson ES, Hartly HO (1958) Biometrikal tables for statisticians, Vol. I. Cambridge University Press, Cambridge

20. Matthews DR (1988) Time series analysis in endocrinology. Acta Paediatr Scand 347 [Suppl]: 55-62

21. Lunbaek K (1972) Intravenous glucose tolerance as a tool in definition and diagnosis of diabetes mellitus. Br Med J 1: 1507-1513

22. Matthews DR, Hosker JP, Rudenski AS, Naylor BA, Treacher DF, Turner RC (1985) Homeostasis model assessment: insulin resistance and $\beta$-cell function from fasting plasma glucose and insulin concentrations in man. Diabetologia 28: 412-419

23. Hansen BC, Jen KJ, Pek SB, Wolfe RA (1982) Rapid oscillations in plasma insulin, glucagon and glucose in obese and normal weight humans. J Clin Endocrinol Metab 54: 785-792

24. Smith CP, Tarn AC, Thomas JM et al. (1988) Between and within subject variation of the first phase insulin response to intravenous glucose. Diabetologia 31: 123-125

25. Smith CP, Archibald HR, Thomas JM et al. (1988) Basal and stimulated insulin levels rise with advancing puberty. Clin Endocrinol 28: 7-14

26. Ganda OP, Srikanta S, Brink SJ et al. (1984) Differential sensitivity to beta-cell secretagogues in "early", Type 1 diabetes mellitus. Diabetes 33:516-521

27. Block MB, Rosenfeld RL, Mako ME, Steiner DF, Rubenstein AH (1973) Sequential changes in beta cell function in insulin treated patients assessed by c-peptide immunoreactivity. N Engl J Med 288: 1144-1148

28. Lefebvre PJ, Paolisso G, Scheen A, Henquin JC (1984) Pulsatility of insulin and glucagon release: physiological significance and pharmacological implications. Diabetologia 30: 443-452 
29. Matthews DR, Hermansen K, Connolly AA et al. (1987) Greater in vivo than in vitro pulsatility of insulin secretion with synchronized insulin and somatostatin secretory pulses. Endocrinology 120: 2272-2278

30. Foulis AK, Stewart JA (1984) The pancreas in recent-onset Type 1 (insulin-dependent) diabetes mellitus: insulin content of islets, insulitis and associated changes in the exocrine acinar tissue. Diabetologia 26: 456-461

31. Stapelfeldt W, Bender H, Schusdziarra V, Pfeiffer EF (1984) Effect of continuous and oscillatory portal vein insulin infusion upon glucose-induced insulin release in rats. Res Exp Med 184: $67-71$

32. Bratusch-Marrain PR, Komjati M, Waldhausl WK (1986) Efficacy of pulsatile versus continuous insulin administration on hepatic glucose production and glucose utilization in Type 1 diabetic humans. Diabetes 35: 922-926
33. Schmitz O, Arnfeld J, Hother Nielsen O, Beck-Nielsen $\mathbf{H}$, Orskov H (1986) Glucose uptake and pulsatile insulin infusion: euglycaemic clamp and [3-3 H] glucose studies in healthy subjects. Acta Endocrinol 113: 559-563

34. Matthews DR, Frank M, Jackson R, Toescu V, Alam S (1988) Normal regular insulin oscillations are absent in gross obesity, old age and mild and severe Type 2 (non-insulin-dependent) diabetes. Diabetologia 31:519 (Abstract)

Received: 12 August 1991

Dr. E. A. M. Gale

Department of Diabetes and Metabolism

St. Bartholomew's Hospital

London EC1A 7BE

UK 